\title{
The Struggle of Indigenous People: An Overview Recognition of Customary Forest in Minangkabau, Indonesia
}

\author{
Dasrizal, Eri Barlian, Afrital Rezki, Rio Tutri, and Farida
}

\begin{abstract}
Customary forest and state forest are still a dichotomy contested by indigenous peoples and the state. The forests around Singkarak Lake, West Sumatra are managed in different ways which are related to the capacity of indigenous communities around the forest. The indigenous Minangkabau people of Nagari Malalo Tigo Jurai have local wisdom for the management of customary forests, but the recognition of their customary forest is beginning to be disturbed by the new recognition of this forest as state forest. This study examines the communal efforts carried out by the indigenous peoples in recognizing the customary forest management rights in Nagari Malalo Tigo Jurai customary forest. This study using a qualitative approach with in-depth interview techniques, observation and literature study. This research shows that there have some local wisdom practiced for forest management in the customary forest area for many years. Lately, there is a strong communal movement of the indigenous peoples for recognition of their customary forest areas.
\end{abstract}

Index Terms-Customary forest, forest management, indigenous people, Minangkabau.

\section{INTRODUCTION}

Forest is one of the natural resources which has various functions and benefits for humans and the environment. Forests as one of natural resources in Indonesia have an area of 124,023,000 ha [1]. Forests have a reciprocal relationship between humans and other living things through ecological processes of life-supporting cycles [2]. Forests provide non-timber potential that can be utilized by the community. There is an increasing pressure on forests as described with the rate of deforestation. Based on data from the Indonesia Ministry of Environmental and Forestry that deforestation rate reaches 450,000 hectares per year [1]. In principle, forests have social, economic and ecological functions for local communities [3]. The potential of local wisdom in forest management can be use as one of the efforts to inhibit the rate of deforestation.

Forest preservation is a description of the relationship between humans and forest ecosystems. Good forest

Manuscript received December 15, 2018; revised April 23, 2019.

Dasrizal is with Graduate School of Padang State University, Indonesia (e-mail: dasrizal204@gmail.com).

E. Barlian is with Padang State University, Indonesia (e-mail: eribarlian@yahoo.com).

A. Rezki and Farida are with Geography Education of STKIP PGRI West Sumatera, Indonesia (e-mail: afrital.rezki@gmail.com, aifarida@yahoo.com).

R. Tutri is with Sociology Education of STKIP PGRI West Sumatera, Indonesia (e-mail: rio_tutri@yahoo.co.id). management should be able to reduce poverty and expand employment opportunities for the community by avoiding inefficient land use. Communities around the forest area develop agroforestry systems as well as one source of livelihood and form of forest management. Access to forests is very important for the community.

Indigenous knowledge is a form of environmental wisdom that exists in specific community and location. Indigenous knowledge refers to certain localities and communities [4], [5]. Referred to [6] confirmed that indigenous knowledge is all forms of knowledge, beliefs, understanding or insight as well as customs or ethics that guide human behavior in the ecological community. Local wisdom in managing the forest is part of the Minangkabau way of living. The Minangkabau people have their life philosophy as "Alam Takambang Jadi Guru" which mean we must take care of the nature because it provide valuables and beneficial to community and the environment [7].

Forest management based on local wisdom in West Sumatra is not only about the procedures for traditional forest management but it also have impacts on the economy of the community. Minangkabau people have a concept of parak (garden) and rimbo (forest). Forest zoning in Minangkabau community that consider ecological function of a forest such as production (parak/olahan) forest, reserved forest and forbidden forest. According to [8] that parak and rimbo is a form of forest resource management based on local knowledge and recognized as a forest management practice by local communities. The concept and application of parak and rimbo have been undergoing dynamic changes over a long period of time considering history and characterizing a local practice.

Indigenous peoples in surrounding Singkarak Lake have been practicing community forest management based on Minangkabau custom through implementation of customary rules in their forest management. Malalo Tigo Jurai is one of the village in Singkarak lake that have strong commitments in protection of their forbidden customary forest. Their commitments are clearly very useful in maintaining the existence of water resources in the area and maintaining residential areas from the threat of landslides. The community in this village applies customary sanctions to anyone who enters the reserved and forbidden forest. The area of customary forest in Malalo Tigo Jurai includes around 10,441 ha which is managed jointly by the community under the customary rules of Malalo Tigo Jurai [9].

The status of customary forest of Nagari Malalo Tigo Jurai in government administration is include in protection forests. 
This condition becoming a problem for the indigenous people in Malalo Tigo Jurai since they have not recognized for their customary forest management. Based on Indonesian Forestry Law No. 41 on the year of 1999 and Law No. 6 on the year of 2014 about the villages, stipulates that the indigenous peoples have rights to the forests which located in areas of their customary law. Thus, the indigenous people of Malalo Tigo Jurai have been carried out collective actions to struggle for the status of their customary forests.

\section{METHOD}

The study used a qualitative approach to express the phenomena which experienced by the research subjects [10]. It was conducted in the indigenous people of Malalo Tigo Jurai which consists of two villages namely Nagari Guguak Malalo and Nagari Padang Laweh Malalo. The informants were selected using snowball sampling technique. The key informants in were formal leaders (village officials) and informal leaders consisting of nagari community leaders (ninik mamak (men), ulama (religious leaders), bundo kanduang (woman leaders), youth and farmer groups). The technique of data collecting was a non-participant observation, in-depth interviews and documentation studies while the data validation used the triangulation method [11]. Data analysis base on Miles and Huberman known as interactive data analysis. It has four steps such as data collection, data reduction, data presentation and conclusion [12].

\section{RESULT AND DISCUSSIONS}

Community-based forest management based on local wisdom is also found to be widely applied by local communities in West Sumatra. Parak and rimbo (forest) are forms of forest resource management based on local knowledge and recognized as a forest management practice by local communities. This condition illustrates that the community has a holistic and embedded view from generation to generation and contains moral and spiritual values in the Minangkabau adat concept. Local knowledge provides a cognitive and instrumental foundation for natural resource management at the local level, including in the management of forest resources.

Utilization and management of forest resources must be optimized while maintaining forest conservation. Many things in forest management bring problems and bring social impacts to communities around the forest area. The problem of forest management by the community often causes polemics. The community considers that the role of the government has not been proportional in managing forests, while the community has problems overlapping the determination of forest management areas.

Nagari (villages) surrounding of Singkarak Lake is an area of natural resources that provides great benefits for the community both economic, social and ecological aspects. They has financial potential, thus increasing economic growth and service. The development of the population within the upper watershed region with its various activities is a major source of decreasing ecological quality for the surrounding of

\section{Lake Singkarak.}

In the surrounding of Singkarak Lake that forest management activities have been taken in the form of activities based on local communities (indigenous peoples) such as community forestry. The local community maintained planting activities enrichment of 500 ha of nagari (village) forest. These activities in Nagari Guguak Malalo by formulating and implementing customary rules in forest management so that the people of Nagari Malalo are consistent in protecting the forest. These commitments and conditions are clearly very useful in maintaining the existence of water resources in addition to maintaining residential areas from the threat of landslides. Even to maintain forest cover, the community applies customary sanctions to anyone who enters the prohibited forest and reserved forest

The indigenous people of Malalo Tigo Jurai consist of three customary groups as Jurai Guguak, Jurai Tanjuang Sawah and Jurai Padang Laweh who lived in two villages namely Nagari Padang Laweh Malalo and Nagari Guguak Malalo. It located in Batipuh Selatan District of Tanah Datar Regency, West Sumatra Province. They acknowledges by the customary law that they have around 10,441 ha of customary forest (based on result of 2014 participatory mapping). Based on the forestry department zonation that the customary forest area in Malalo Tigo Jurai is part of other used area covering 2,085 ha, protected forest covering 3,590 ha and Bukit Barisan I nature reserve area of 4,766 ha [9].

The basis of Minangkabau customary law in the forest management is related to relationship of the people with the environment. The value of the forest is not only for the economical needs but also about how indigenous people honored the value of live harmoniously and be economically, socially and culturally sustainable. The geographical condition of MalaloTigo Jurai is part of the consideration of the indigenous people in managing their customary forest (Fig. $1)$.

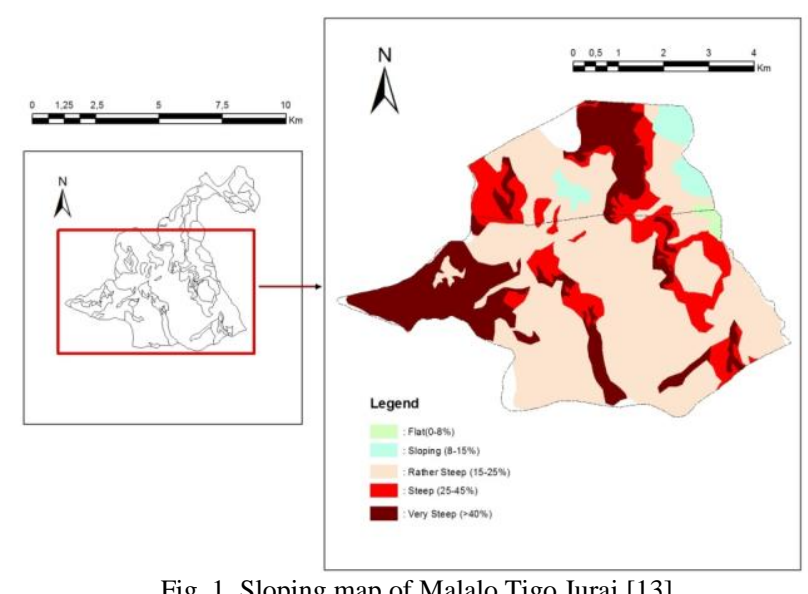

Fig. 1. Sloping map of Malalo Tigo Jurai [13]

The area of Malalo Tigo Jurai is dominated by very steep and steep slope (Fig. 1). This condition induced the community to divide the land use based on the slope and the distance from the Singkarak Lake consist of:

1) Rimbo forest, forest which located in ulayat nagari area (communal ancestral land of the village) dominated by trees, animals and forest ecosystem. The community have to maintain the ecosystem in rimbo forest. Rimbo forest is located in very steep and steep slope in the 
village.

2) Parak is forest area planted with economically trees (clove, coffee, nutmeg, teak, etc.) and its belong to eleven clans in Malalo Tigo Jurai. The location of parak is under the stake of rimbo forest.

3) Paddy field is management areas under cultivation and it divided and belong to the clans.

4) Residential area is located in relatively flat and close to Singkarak Lake

Based on the custom agreement among the clans, that the area with very steep slope, part of water reservation area and close to the river are become part of forbidden forest, even though these area is supposed to be part of ulayat suku land. This area have to be planted and keep as forest in order to prevent from the landslide and for water source.

The ninik mamak (custom leaders) of Malalo Tigo Jurai have agreed on the division and zonation of forest management and utilization as :

1) Forbidden (larangan) forest is a ulayat nagari forest which has not been divided into the eleven clans that are located above bosweisen (boundary mark of forest utilization made by the Dutch in the colonial time). This is a protection forest where people not able to use the trees and non tree forest products.

2) Reserve (cadangan) forest is the forest area which has not been divided into the clans but it still available to be utilized as agricultural field when the population is increasing. The utilization of reserve forest will need the permit from ninik mamak in Kerapatan Adat Nagari/KAN (village legislation council).

3) Paramuan forest is the forest where people able to take the tress for building purposes as well as for planting valuable trees such as clove, nutmeg, candlenut, etc. The trees from this forest are not allowed to be sell and normally only for building houses and public facilities in the village.

The land management in Malalo Tigo Jurai is part of the characteristics of local wisdom in elaboration of the principal of the indigenious people in dealing with external culture. This condition will make the people are not so much dependent on external culture [14].

Local wisdom is a creative answer to local geographical-political, historical, and situational condition [15]. Indigenous people's aware of the importance of protecting the forests, since most of their land located on the hilly and steep side of Singkarak Lake. One of the important agreement among the customary group is a prohibition to cut down the trees in the catchment area and in steep areas (slope more than $40 \%$ ). This agreement was made to prevent the area from flash flood which had hit the area several times as well as to maintain the availability of water used agricultural irrigation.

Forest protection is one of the main concern of the indigenous people of Malalo Tigo Jurai. This is reflected in one of the local rule that the man has to plant fifty trees as one of requirement in getting his marriage paper. This rule was made in 1970 since they realized that they had quite amount of critical land and to protect of the forests. They also have their local wisdom practices for water regulation such as aia adaik (irrigation water that is evenly divided) and mambukak kapalo banda (mutual agreement on planting season time, type of seed to be planted, water distribution for agricultural and other rules related to rice field management based on ranji (ownership based on the family ancestral).

The local environmental wisdom for forest management as part Malalo Tigo Jurai customary law began to be disturbed when the government planned to establish a protected forest located in Malalo Tigo Jurai. The community believed that their customary forest has the same function of protected forest established by the government regulation. The change into protected forest by government will make they loss their management rights in customary forest and that has been inheritaged from generation to generation. The conflict about the forest boundary occurred in 2003 when the forestry district and provincial office tried to set up new forest boundary in the area. This become a starting point for the indigenous people of Malalo Tigo Jorong to struggle for their customary forest right.

In protecting the existence of the customary forest then the indigenous people of Malalo Tigo Jurai involved the village elements namely niniak mamak (clan leaders), alim ulama (religious leaders) and cadiak pandai (people who considered as intelligent) [16] dan [17]. These three elements are legalized by the village decree known as Surat Keputusan by Nagari Guguak Malalo and Nagari Padang Laweh Malalo.

Indonesian government released Undang-Undang nomor 18 tahun 2013 [18] (law) about prevention and eradication of forest destruction. Based on this law that the Ministry of Forestry stipulates that 500 meters from the shoreline of Singkarak Lake are designated as protected forests area. The indigenous people of Malalo Tigo Jurai think that this new regulation considered to have a potential to criminalize the communities. The new regulation will seize right of the community to their customary forest zonation and functions.

The community organized to form a customary forest struggle group called Lembaga Peduli Ulayat Malalo Tigo Jurai. This organization consist of 19 people as presentative of the community which include niniak mamak, alim ulama dan cerdik pandai. Lembaga Peduli Ulayat Malalo Tigo Jurai applied for the judicial review of law No 18 of 2013 to the constitutional court. One of the background to apply for the judicial review was the opportunity for indigenous people in forest management through the judicial court decision of MK No 35 Tahun 2012 [19] on customary forests. Definition of customary forest based on MK No 35 of 2012 is the forest within the territory of indigenous peoples. The movement of Lembaga Peduli Ulayat Malalo Tigo Jurai was accompanied and supported by local NGO alliances as Kelompok Timbulun (Timbulun Team) from Perkumpulan Qbar, Walhi, Warsi and Lembaga Bantuan Hukum.

Lembaga Peduli Ulayat Malalo Tigo Jurai and Timbulun team had been tried their efforts on defending their customary forest status. One of the effort was attending the national meeting with Ministry of Environmental and Forestry in Jakarta (2015) and also held public discussions and outreach (2016) to encourage recognition of the customary law on forest management and zonation as the basis for ownership and control of their customary forests. They have also supporting in preparation of the academic manuscript for Tanah Datar Regency regulation draft on recognition of the indigenous peoples of Malalo Tigo Jurai. It is a very 
important step in pushing the Tanah Datar government to have a regencies regulation on customary forest. Another important activity is to provide the capacity building for the youth of the Malalo Tigo Jurai in strengthening their way of thinking about recognition of their customary forest.

\section{CONCLUSION}

The indigenous people of Malalo Tigo Jurai which consists of Jurai Guguak, Jurai Tanjuang Sawah and Jurai Padang Laweh are a group customary community who live in two village of Nagari Padang Laweh Malalo and Nagari Guguak Malalo. They have practices local wisdom in forest management for years and have special forest zonation based on its ecological function and utilization. The overlapping between government and customary regulation has triggered the community to form an organization that can fight for their rights to the status of their customary forests. The government need to recognized the existence of customary forest as well as the local practices for forest management as part of forest protection program.

Indigenous peoples have a strong motivation in maintaining the existence of forests because this concerns the sustainability of their lives. Indigenous peoples have customary laws and institutions that regulate harmonious interactions between communities and forest ecosystems. Forest management based on local wisdom in West Sumatra is not only about the traditional forest management procedures, it can have an impact on the economy of the community. Forest resources are shared resources that have benefits to realize sustainable development. The many benefits found in forests tend to make the surrounding community prioritize forest resources as a source of their livelihood, but if the resources in the forest are continuously exploited, it will have a negative impact on humans and the surrounding environment.

\section{CONFLICT OF INTEREST}

The authors declare no conflict of interest.

\section{AUTHOR CONTRIBUTIONS}

Dasrizal, E. Barlian and A. Rezki conducted the research wrote the paper. Farida and R. Tutri analyzed the data and wrote the paper. All authors had approved the final version

\section{REFERENCES}

[1] BPS, Luasan Hutan dan Konservasi, 2015.

[2] S. B Reksohadiprodjo, Ekonomi Lingkungan, Yogyakarta: BPFE Yogyakarta, 2000.

[3] B. Hendryo, Hutan Indonesia Paru-Paru Dunia, Jakarta: Verbum, 2013.

[4] Suhartini, Kearifan Lokal Masyarakat dalam Pengelolaan Sumberdaya Alam dan Lingkungan, in Seminar Nasional Penelitian, Pendidikan dan Penerapan MIPA, Fakultas MIPA, Universitas Negeri Yogyakarta, 2009.

[5] E. H. Yulianto, "Konservasi tradisional berbasis kearifan lokal masyarakat tani kab paser (studi kasus desa simutai kecamatan long ikis kabupaten paser)," AGRIFOR, vol. 12, pp. 140, 147, 2013.

[6] S. A. Keraf, Etika Lingkungan, Jakarta: Buku Kompas, 2002.

[7] N. Idris, "Kedudukan perempuan dan aktualisasi politik dalam masyarakat matrilinial minangkabau," Jurnal Masyarakat, Kebudayaan dan Politik, vol. 2, no. 2, pp. 108-116, 2015.
[8] F. Asmin, "Modal sosial dalam pengelolaan hutan berbasis masyarakat di sumatera barat," Phd dissertation, Natural and Enviromental Resource Management, Bogor Agricultural University, 2017.

[9] Dasrizal, Laporan Wawancara: Kearifan Lokal Masyarakat dalam Pengelolaan Hutan di Salingka Danau Singkarak, 2018.

[10] L. Moleong, Metode Penelitian Kualitatif, Bandung: Remaja Rasda Karya, 2013.

[11] Nasution, Metode Research, Jakarta: PT. Bumi Aksara, 2003.

[12] B. M. Miles and A. M. Huberman, Analisis Data Kualitatif, Jakarta: UI Press, 1992.

[13] Bappeda, Rencana Tata Ruang Wilayah Kabupaten Tanah Datar, 2015.

[14] Daryusti, Lingkaran Lokal Genius dan Pemikiran Seni Budaya, Yogyakarta: Multi Grafindo, 2010.

[15] C. E. Permana, Kearifan Lokal Masyarakat Baduy dalam Mengatasi Bencana, Jakarta: Wedatama Widia Sastra, 2010.

[16] M. Anjela, "Pergeseran peran ninik mamak terhadap kemenakan dalam adat minangkabau di kanagarian simalanggang," Jurnal Online Mahasiswa Fakultas Ilmu Sosial dan Politik UNRI, vol. 1 no. 2, 2014.

[17] Sulastri, C. Andriani, and Y. F. Fitria, "The Factors forming formal and non-formal leadership based on minangkabau culture in padang," Journal of Asia Pasific Management, Bussiness Application, vol. 6, no. 1, pp. 2-17.

[18] Undang-Undang Republik Indonesia Nomor 18 Tahun, 2013.

[19] Putusan Mahkamah Konstitusi, 2012.

Copyright $(\odot) 2019$ by the authors. This is an open access article distributed under the Creative Commons Attribution License which permits unrestricted use, distribution, and reproduction in any medium, provided the original work is properly cited (CC BY 4.0).

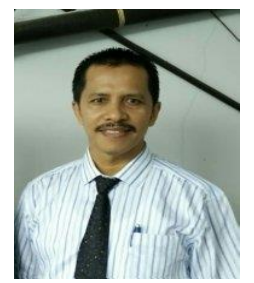

Dasrizal was born in Sawah Kareh in 1965. He obtained his bachelor degree (1990) on geography education of IKIP Padang, West Sumatra and the master degree on soil science (2003) in Andalas University, West Sumatra. He is currently doing his $\mathrm{PhD}$ (from 2016) on environmental science at Padang State University, West Sumatra. His dissertation research is on local knowledge of forest management in Singkarak Lake, West Sumatra.

$\mathrm{He}$ is a senior lecturer at STKIP PGRI Sumatera Barat (teacher college) of Geography Education Department since 1991. He has worked as project leader in various research scheme funding by Ministry of Higher Education of Republic of Indonesia. His research interest in the area of physical and human geography. This article is derived partly from his dissertation work.

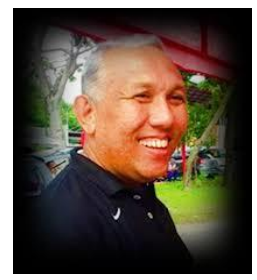

Eri Barlian was born in Padang in 1961. He had his bachelor degree in sport education of IKIP Padang in 1986. His master degree in environmental science at University of Indonesia (1991) and his $\mathrm{PhD}$ on education from Jakarta State University in 1999. Since 1999 he is a lecturer at graduate school of Padang State University and currently the head of Environmental Science doctoral program.

He has various experience in assisting sport science project as well as the environmental research. His research interest in natural resource management and environmental impact. He has several national papers in national journal and papers in national and international proceeding.

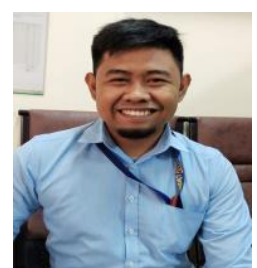

Afrital Rezki was born in Rambatan in 1986. He had his bachelor degree in geography education at Padang State University (2010) and his master degree in geography of University of Indonesia (2013). He is junior lecturer at Geography Education Department of STKIP PGRI Sumatera Barat (teacher college) since 2014. His expertise in application of remote sensing and geographic information system for natural resource management. 


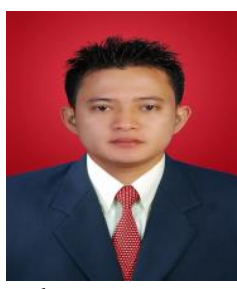

Rio Tutri was born in Barulak in 1985. He obtained his bachelor degree in sociology (2009) at Andalas University, West Sumatra. He continued his master degree in sociology also in Andalas University (2012). He joined as junior lecturer at Sociology Education of STKIP PGRI Sumatera Barat (teacher college) since 2015. He is teaching and research interest in the area of environmental sociology, social and poverty.

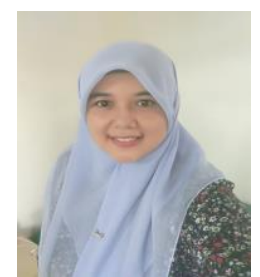

Farida was born in Bukittinggi in 1977. She had a bachelor degree in agricultural meteorology from Bogor Agricultural University. She continued her master study on tropical hydrology and environmental management at TU Darmstadt, Germany. She is lecturer at Geography Education Department of STKIP PGRI Sumatera Barat since 2012. Her research interest on water resource management and climate change. 